\title{
2.3 Особливості роботи психолога і тренера у процесі становлення сучасного спортсмена
}

Становлення сучасного спорту передбачає необхідність психологічного супроводу спортсмена в ході тренувальної та змагальної діяльності. Часто фізично і технічно добре підготовлені спортсмени програють тільки через психологічну неготовність. Багато фахівців у сфері фізичної культури і спорту вважають, що і тренер, і спортсмен повинні самостійно виконувати функції психолога. Однак практика показує, що не лише спортсмен потребує психологічної допомоги, а й тренер. Недооцінка значущості такого виду роботи в професійній діяльності психолога часто призводить до поразок на змаганнях високого рівня. Аналіз досліджень в галузі спортивної психології () показав, що, незважаючи на те, що є велика зацікавленість до ролі тренера в підготовці спортсмена, багато аспектів його професійної діяльності залишаються невивченими. Успішна взаємодія в системі «тренер-спортсмен-психолог» можлива лише при всебічному вивченні кожного компонента цієї системи.

Значна кількість діячів фізичної культури і спорту зробили внесок у розвиток психології спорту. Основоположниками цієї науки стали: Триплетт Н., який працював в Індіанському університеті і був прихильником велосипедного спорту, провів перший експеремент і помітив, що велосипедисти швидше проходять дистанцію в гонці з суперником, ніж у гонці на час.; Лесгафт П.Ф. опублікува першу у світі науково обгрунтовану концепцію фізичного виховання, що спирається на анатомо-фізіологічні, гігієнічні та психологічні основи, Нечаєв О.П. став родоначальником лабораторії експериментальної педагогічної психології і психотехніки; Чиж В.Ф. вивчав проблеми психології різних соціальних явищ; П'єр де Кубертен був організатором конгресу спортивних психологів, який відбувся в Лозанні (Швейцарія) у 1913 р.; Рудік П.А. - доктор психологічних наук, під керівництвом якого були проведені дослідження у галузі спортивної психології; Пуні А.Ц. - у Ленінградському інституті фізичної культури імені П.Ф. Лесгафта ввів і читав лекційний курс «Психологія фізичного 
THEORETICAL FOUNDATIONS OF THE FUNCTIONING OF EDUCATION. WAYS TO

IMPROVE THE EFFECTIVENESS OF EDUCATIONAL ACTIVITIES

виховання і спорту» (1946/47 н.р.); Ноель-Бейкер Ф. президент Міжнародної ради 3 питань спорту та фізичного виховання; Ферруччо Антонеллі був ініціатором I установчого конгресу Міжнародного співтовариства спортивних психологів 1965 р. в Римі. Також наразі добре відомі праці зарубіжних психологів спорту: Ванека М., Васілевскі Е., Кретті Б. Д., Мацака І., Мюллера 3., Навроцкой Б., Рокушфалві П., Шіллінг Г., Яффі М. та ін.

Психологія спорту - напрям психологічної науки, предметом дослідження якої є вивчення закономірностей прояву і розвитку психіки людини, а також групових взаємодій в умовах змагальної та тренувальної діяльності. (Корносенко, 2000, с. 5)

Психологія спорту розробляє психологічні основи навчання й виховання спортсменів в умовах змагального процесу, розкриває закономірності вироблення спортивних навичок та вмінь, досліджує поведінку спортсменів в умовах змагального процесу, розкриває закономірності формування вольових та моральних якостей, необхідних для досягнення перемоги у спортивних змаганнях. (Гогунов, 2002. с.5).

Психологія спорту - спеціальна галузь психологічної науки, предметом якої є психологічні особливості спортивної діяльності в їі різноманітних видах і психологічні особливості особистості спортсмена. Психологія спорту як спеціальна галузь психологічної науки вивчає закономірності прояву й розвитку психіки діяльної особистості у специфічних умовах фізичного виховання i спорту. (Гогунов, 2002. с.5).

Визначення ролі психолога у спорті займає чільне місце, до цього в якості психолога виступав тренер, який займався зі спортсменом, це зумовлено тим, що в Радянському союзі психологічна освіта отримала масовий характер лише в кінці XX ст., а організація підготовки психологів за кордоном орієнтується на традиції психологічного освіти, що склалися в США

в кінці XIX ст.(Гогунов, 2000, с. 47) Безумовно, хороший тренер володіє основами психології. Однак у тренера все ж головне завдання - це спортивні досягнення вихованців: голи, секунди, метри. Спортивний психолог, у свою 
THEORETICAL FOUNDATIONS OF THE FUNCTIONING OF EDUCATION. WAYS TO IMPROVE THE EFFECTIVENESS OF EDUCATIONAL ACTIVITIES

чергу, в процесі тренувань і змагань звертає увагу на підвищення стресостійкості спортсмена. Допомога психолога у спорті відноситься до галузі класичної психології (Гогунов, 2000, с. 47). Якісне регулярне консультування спортивного психолога налагоджує всі сфери: тренувальний процес, спілкування з людьми в повсякденному життя.

Робота спортивного психолога носить різнобічний характер: питання підвищення результатів, ефективності спортивної діяльності дають відповіді, які виходять за межі спорту i змагань. Перед спортивним психологом стоїть завдання розуміння і оцінки власних дій i їх наслідків, можливих способів кооперації з іншими фахівцями та досягнення продуктивних відносин зі спортсменом.( Яковлев, 2014, с. 145)

Головним суб’єктом такої кооперації є- тренер. У спорті тренер, безумовно, найголовніший наставник, причому для юного спортсмена він є ще й орієнтиром в становленні особистості. Спостерігаючи за розвитком професійного спорту в нашій країні, можна зробити висновок, що тренеру, крім прямих професійних обов'язків, доводиться виконувати функції менеджера, адміністратора i, звичайно, психолога. Але основними причинами, чому тренер не може повністю замінити психолога, полягає в тому, що проблема може бути непомітною для недосвідченого ока. По-друге, базові знання з психології, які отримані під час навчання у ЗВО або здобуті з популярної літератури, нерідко створюють ілюзію про здатність вирішити будь-яку психологічну проблему, а неграмотне застосування психотехнік може призвести до негативних наслідків. Сказане, звичайно, не відноситься до тих людей, хто серйозно намагається зрозуміти і розібратися в механізмах роботи психіки та способи впливу на неї. Адже більшість спортивних психологів - це спортсмени або тренери, які глибоко знають і спорт, і психологію. Основною метою роботи психолога є «буферізація» між тренером і гравцем. Якщо тренер налаштовує спортсмена на перемогу, розвиваючи спортивну злість і інші види поведінки, які викликають стрес, то психолог, маючи в арсеналі сучасні методики, пом'якшує тиск, не впливаючи при цьому на досягнення хорошого результату. У системі «тренер-спортсмен- 
THEORETICAL FOUNDATIONS OF THE FUNCTIONING OF EDUCATION. WAYS TO

IMPROVE THE EFFECTIVENESS OF EDUCATIONAL ACTIVITIES

психолог» саме спортсмен є ключовою фігурою. Мотивація до спортивної діяльності виступає в ролі системоутворюючого фактору, а механізм зворотного зв’язку - є успішний результат спортсмена. Саме формування мотивації до спортивної діяльності, до досягнення високих результатів $є$ однією 3 найважливіших задач психолога i тренера. Лише цілеспрямована взаємодія психолога і тренера може дозволити дійти до успішного фінішу.

Взаємозв’язок у системі «тренер-спортсмен-психолог» доцільно розглядати через функції, які виконує кожен із суб'єктів процесу тренування (Табл. 1).

Таблиця 1

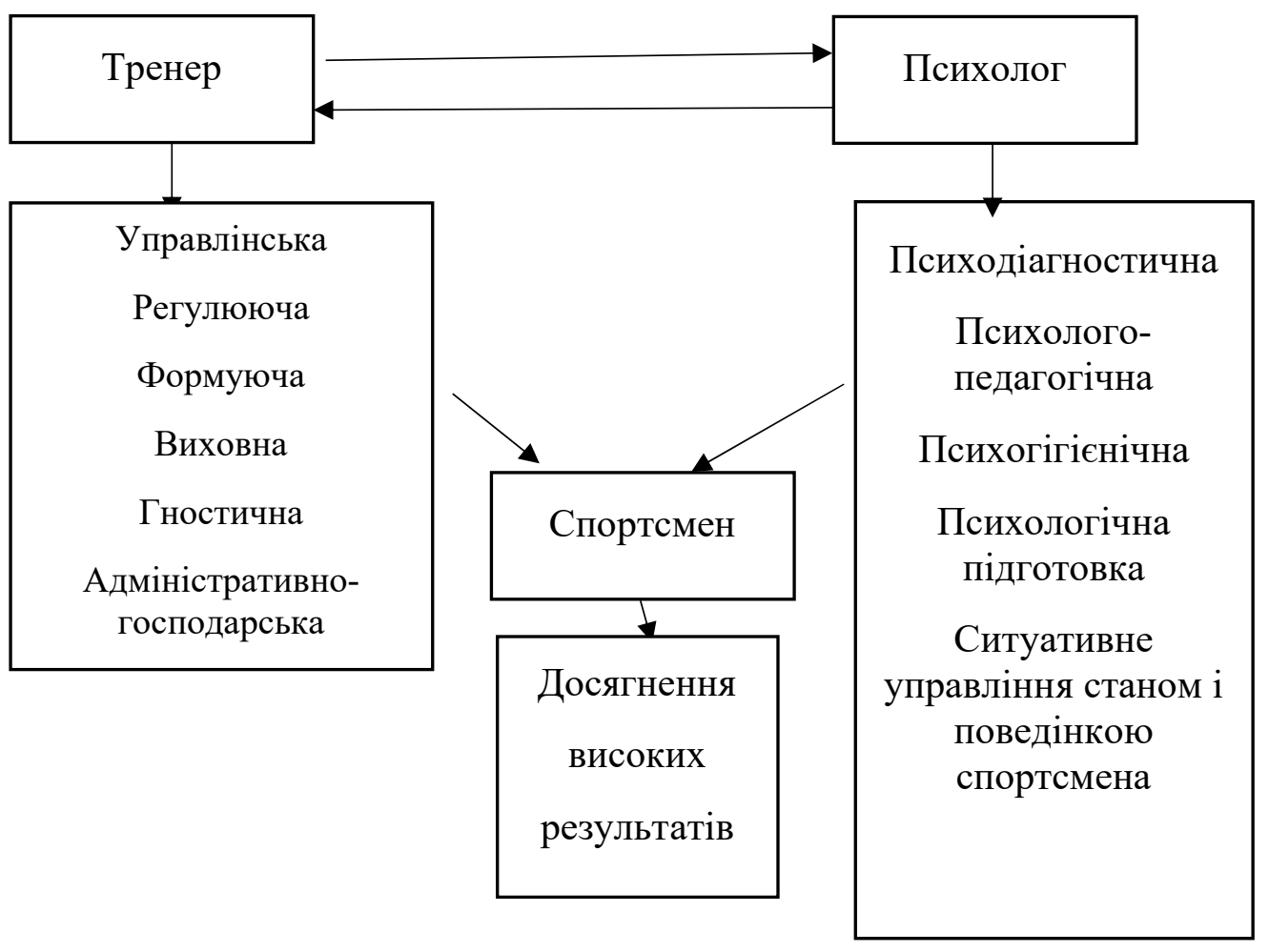

Управлінська функція тренера передбачає аналіз інформації для приймання управлінських рішень, від правильності яких залежить успіх його вихованців. Завдяки цій функції, саме тренер є головнокомандувачем у системі «тренер-спортсмен-психолог», який своїми діями впливає на кінцевий результат спортсмена, а також на подальшу діяльність психолога. Саме управлінська 
THEORETICAL FOUNDATIONS OF THE FUNCTIONING OF EDUCATION. WAYS TO

IMPROVE THE EFFECTIVENESS OF EDUCATIONAL ACTIVITIES

функція тренера дає змогу психологу формувати вольову готовність до виступу на змаганнях.

Виконуючи регулюючу функцію, тренер тісно взаємопов'язаний iз психологом. Напередодні змагань спортсмен перебуває в стані близькому до психічних зривів, до перевтомлення. Основним завданням і психолога, і тренера є знайти причини зриву, максимально переключити увагу на сприятливі думки, за допомогою психорегулюючих вправ і методик відновлення спокою.

За допомогою формуючої функції тренер забезпечує організацію навчально-педагогічного процесу, а завдання психолога максимально сприяти розвитку психічних функцій (уваги, мислення, пам’яті, сприймання). Для успішного кінцевого результату формування рухових якостей і психічних явищ здійснюється в екстремальних умовах тренувальної і змагальної діяльності. Цей процес проходить на базі автоматизованого управління діями, що складаються 3 певної системи рухів.

Психолого-педагогічна функція психолога i виховна тренера тісно взаємопов’язані. Тренер разом 3 психологом має сформувати дружний згуртований колектив, в якому кожен окремий його член відчуває загальну підтримку, турботу. Як тренер, так і психолог мають володіти якостями i навичками, необхідними для педагогічної і тренерської діяльності.

Психологічна підготовка і гностична функція мають спільну мету надання спортсмену необхідних знань i умінь, стимулювання його до пізнавальної активності, до загальної психологічної підготовки тренувань і змагань, до корекції психічних процесів на завершальному етапі підготовки до змагань.

Адміністративно-господарська функція тренера має безпосередній вплив у системі «тренер-спортсмен-психолог». Завдяки ій відбувається матеріальне забезпечення тренувального процесу, пошук і фінансування змагань.

Важливу роль у розвитку особистості спортсмена і на подальшу діяльність тренера відіграє психодіагностика. Завдяки саме психодіагностиці відбувається формування психолого-педагогічних i психогігієнічних рекомендації, 
THEORETICAL FOUNDATIONS OF THE FUNCTIONING OF EDUCATION. WAYS TO

IMPROVE THE EFFECTIVENESS OF EDUCATIONAL ACTIVITIES

планування системи дій на спортсменів. Психодіагностика ставить за мету вивчення спортсмена. Тренер в цьому процесі допомагає об’єктивно оцінити особистість спортсмена.

Психогігієнічні рекомендації психолога і тренера мають тісний зв'язок. Адже в системі «тренер-спортсмен-психолог» вони напряму впливають на психічний стан спортсмена.

Виходячи з вищезазначеного, можна сказати, що тісна співпраця тренера $\mathrm{i}$ психолога забезпечить досягнення результатів спортсмена. Значна кількість фахівців фізичної культури, які задіяні у процесі підготовки спортсменів до змагань, розуміють значення психологічних факторів, які впливають на ефективність і результативність спортсмена. Але мало хто вважає за необхідне приділяти постійну увагу знанням теорії i практики психології спорту у тренувальній і змагальній діяльності спортсмена. Тенденцію обов’язкової присутності психолога в команді в періоди підготовки або під час проведення змагань можна спостерігати у зарубіжних країнах, де психолог - штатний працівник.

Беручи до уваги спостереження за спортсменами нашої держави, варто зазначити, що зараз все ще не приділяється уваги системній роботі психолога у підготовці спортсмена. Існує декілька причин, які призвели до появи недовіри 3 боку тренерів до психолога. По-перше, так відбувається, коли тренер змушує розібратися в проблемі спортсмена в короткочасний період, нехтуючи спланованим курсом психологічної підтримки. По-друге, це відмінності в установках тренера та спортсмена. Так відбувається тоді, коли тренер вимагає від психолога виконання конкретних завдань стосовно підготовки спортсмена, але сам не співпрацює з ним, не виконуючи поради та рекомендації. По-третє, у особистості психолога має поєднуватися специфічні особливості спортивної діяльності та психологічні моменти кожного конкретного виду спорту.

Різноплановість у роботі тренера, важливість низки допоміжних функцій у роботі останнього (адміністрування, регулювання, управління) не дає можливості адекватно оцінювати проблеми та негаразди спортсмена як 
особистості. Саме в цьому полягає завдання спортивного психолога - створити атмосферу цілковитої довіри та взаєморозуміння, встановити контакт зі спортсменом для розкриття особистих проблем, який дозволить ефективно вплинути на його стан.

Таким чином, взаємозв'язок тренера і психолога у процесі професійної діяльності має велике значення на кар'єру спортсмена. Роль психолога у спорті $\epsilon$ багатогранною, яка спрямована на підготовку спортсмена до змагань.

Психологічна підтримка 3 боку психолога носить профілактичний i коригуючий характер, спираючись на психопедагогічні функції. У тісному взаємозв'язку психолога i тренера спортсмен має можливість оволодіти прийомами аутопідтримки та аутокорекції. Це дасть можливість самостійно вирішувати нагальні психологічні потреби.

Подальші наукові дослідження можуть стосуватися розроблення методик впливу на психіку спортсмена у передзмагальний і змагальний період. 